\title{
Kabataia gen. n., a new genus proposed for Microsporidium spp. infecting trunk muscles of fishes
}

\author{
Jiří Lom ${ }^{1, *}$, Iva Dyková ${ }^{1}$, Kamonporn Tonguthai ${ }^{2}$ \\ ${ }^{1}$ Institute of Parasitology, Academy of Sciences of the Czech Republic, Branišovská 31, 37005 České Budějovice, \\ Czech Republic \\ ${ }^{2}$ Aquatic Animal Health Research Institute, Kasetsart University Campus, Bangkok 10900, Thailand
}

\begin{abstract}
Based on a fine structural study, a new genus, Kabataia gen. n., is proposed for Microsporidium arthuri Lom, Dyková and Shaharom, 1990. It develops in trunk muscles of a South-East Asian freshwater fish, Pangasius sutchi. The genus has nuclei isolated throughout the cycle, merogony stages are multinucleate, sporogony proceeds in 2 steps: multinucleate sporont segments into sporoblast mother cells which produce 2 sporoblasts. Sporoblasts and early spores are characterized by a dense globule at the site of the posterior vacuole. Mature spores are of a rather variable shape. Their exospore is raised into small, irregular fields. The polaroplast is relatively small and its posterior part consists of flat vesicles with dense contents. The polar tube makes a small number $(4$ to 6$)$ of turns. A congeneric species is Kabataia seriolae (Egusa, 1982) comb. nov. from cultured marine yellowtails Seriola quinqueradiata. Kabataia inflicts heavy damage on muscle tissue. The sarcoplasm within which Kabataia develops is reduced to an amorphous mass with tubule-like fibrils, microfibrils and small vesicles.
\end{abstract}

KEY WORDS: Microsporidia - Kabataia gen.n. · Ultrastructure $\cdot$ Pangasius sutchi

\section{INTRODUCTION}

Until now, about 90 named species of microsporidia infecting fishes have been established. They were assigned to the genera Glugea Thélohan, 1891, Heterosporis Schubert, 1969, Ichthyosporidium Caullery and Mesnil, 1905, Loma Morrison and Sprague, 1981, Microfilum Faye, Toguebaye and Bouix, 1991, Microgemma Ralphs and Matthews, 1986, Neonosemoides Faye, Toguebaye and Bouix, 1996, Nucleospora Hedrick, Groff and Baxa, 1991, Pleistophora Gurley, 1893, Spraguea Vávra and Sprague, 1976 or Tetramicra Matthews and Matthews, 1980. The single record of the genus Jirovecia Weiser, 1977 in fish intestine was probably due to a fortuitous ingestion of an infected prey organism. Assignment of some species to the

\footnotetext{
•E-mail: lom@paru.cas.cz
}

genus Thelohania Henneguy, 1892 appears quite untrustworthy. Several species of unclear affinities were included into the collective group Microsporidium Balbiani, 1884. The number of existing species and perhaps genera obviously largely exceeds the taxa recorded thus far. Thus Faye (1992) presented sketchy descriptions of 20 unidentified Microsporidium spp. from marine fishes collected off the coast of Senegal.

The recently growing interest in fish microsporidia is reflected, among other things, by the recruitment of molecular techniques to clarify the taxonomic situation (in Nucleospora, Docker et al. 1997) or to differentiate between intraspecific or intrageneric categories (in Loma-work in progress, see Shaw \& Kent 1999). However, the impact of molecular studies has not reduced the importance of classical ultrastructural studies. They can still be used in finding the true generic position of some of the Microsporidium species. Thus $M$. ovoideum (Thélohan, 1895) has 
been reassigned to the genus Microgemma by Amigo et al. (1996). Similarly, the purpose of the present paper was to investigate the accurate generic position of some of the muscle-infecting Microsporidium species from South-East Asian fishes. The model used is the organism infecting the freshwater fish Pangasius sutchi, important as both ornamental and commercial species.

\section{MATERIAL AND METHODS}

Four specimens of Pangasius sutchi (Fowler, 1937) about $3.5 \mathrm{~cm}$ in length were collected on a fish farm in the Bangkok region (Thailand), and revealed signs of microsporidian infection. White patches were visible through the skin. The fishes were sacrificed and fresh spores were photographed using the agar layer method (Lom \& Dyková 1992) and measured in prints enlarged at a specified magnification. Samples of the tissues were processed for histology and for transmission electron microscopy. To this purpose, tissue blocs were fixed in $2.5 \%$ glutaraldehyde in sodium cacodylate buffer, postfixed in $1 \%$ osmium tetroxide and embedded in Epon-Araldite. Ultrathin sections were double stained in uranyl acetate and lead citrate and observed in a Jeol JEM 1010 electron microscope at the accelerating voltage of $60 \mathrm{kV}$.

\section{RESULTS}

\section{Light microscopy of spores}

Spores were mostly oviform; their considerable variation in shape included ellipsoidal, slightly curved, anteriorly tapered and even subspherical forms (Fig. 1). The size of fresh spores was $3.1(2.2$ to 4.2$) \times 1.9(1.5$ to 2.4) $\mu \mathrm{m}(\mathrm{n}=25)$. The large, globular posterior vacuole had an average length of $1.2(0.7$ to 1.7$) \mu \mathrm{m}$. The polar tube could not be discerned in live spores.

\section{Electron microscopy}

Meronts

Meronts appeared in sections as uninucleate cells that obviously developed into multinucleate stages which were rounded (Fig. 2) or elongated (Fig. 3). They had a rather dense cytoplasm full of ribosomes and nuclei with a distinct nucleolus. Their plasmalemma was coated by a dense glycocalyx layer approximately 20 to $24 \mathrm{~nm}$ thick (Fig. 4). Meronts divided by plasmotomy and binary fission.

\section{Sporonts}

Multinucleate meronts transformed into sporonts by acquiring an increasingly thicker cell coat while their cytoplasm grew thinner. Sporonts started division by segmenting (Figs. 5 \& 6) into uninucleate stages. The uninucleate cells did not transform into sporoblasts directly, this was preceded by binary fission (Fig. 7); thus, actually, these dividing cells have to be taken for sporoblast mother cells. The dense coat of the sporogony stages appeared first in isolated patches (Fig. 8). Sporogony stages revealed projections radiating from their surface (Fig. 9) and were surrounded by dense vesicles which were not necessarily transverse sections of tubules. The projections had the shape of stout tubules; occasionally, blisters were observed delaminating from the cell wall (Fig. 10)

\section{Sporogony}

In the early sporoblast, when its wall was still crumpled, persisting dense projections could still be occasionally observed to extend from the sporoblast wall (Fig. 11). At the same time, a dense globule appeared posterior to the nucleus (Fig. 11), appearing to be connected with (and produced by?) the network of the primitive Golgi system. The globule persisted in the developing sporoblasts up to the stage of immature spore (Figs. $12 \& 15$ ). Thus the globule may be associated with the formation of the posterior vacuole by which it is eventually replaced.

The early sporoblast revealed the foundation of the polar sac (Fig. 13) from which the tube started to extend. The tube appeared first as a simple hollow structure with a dense core (Figs. 11 \& 14). Ribosomes were situated on the rather indistinct cisternae of the endoplasmic reticulum enveloping concentrically the nucleus. The exospore, first unstructured, reached its final thickness faster than the endospore.

\section{Mature spores}

The layer of the exospore-altogether 46 to $52 \mathrm{~nm}$ thick - was divided into small irregular fields seen on cross- (Fig. 13) as well as on grazing sections (Fig. 17). The fields were separated by incisions reaching approximately 30 to $35 \mathrm{~mm}$ down almost to the endospore layer. The exospore fields were covered by a thin lucent sheet overlain by a thin roughly granular stratum (Fig. 13). The average thickness of the endospore was $90 \mathrm{~nm}$; its thinnest area was in front of the anchoring apparatus of the tube. 


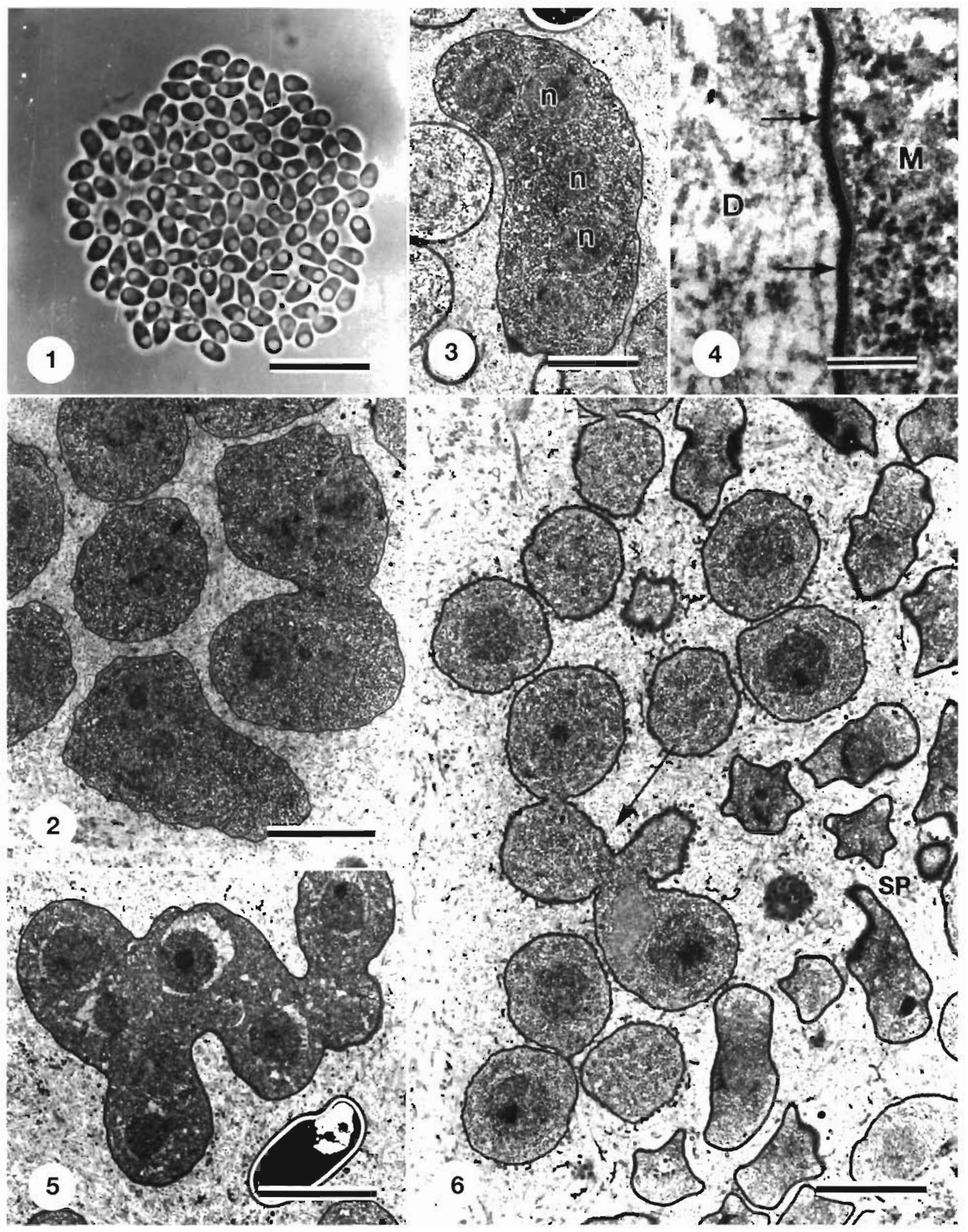

Fig. 1. Fresh spores of Kabataia arthuri Scale bar $=10 \mu \mathrm{m}$. Figs 2 to 6 . Transmission electron micrographs. Fig. 2. Rounded merogony stages. Fig. 3. An elongated, multınucleate meront. $\mathrm{n}=$ nucleus Scale bar $=5 \mu \mathrm{m}$. Fig. 4 . Dense deposit (arrows) on the meront $(\mathrm{M})$ plasmalemma. $\mathrm{D}=$ destroyed sarcoplasm. Scale bar $=2 \mu \mathrm{m}$ Fig. 5 . A multinucleate sporont dividing by segmentatıon Scale bar $=250 \mu \mathrm{m}$. Fig. 6 . A group of sporogony stages, some in division (arrow) next to early sporoblasts (SP) $\mathrm{Scale}$ bar $=2 \mu \mathrm{m}$ 


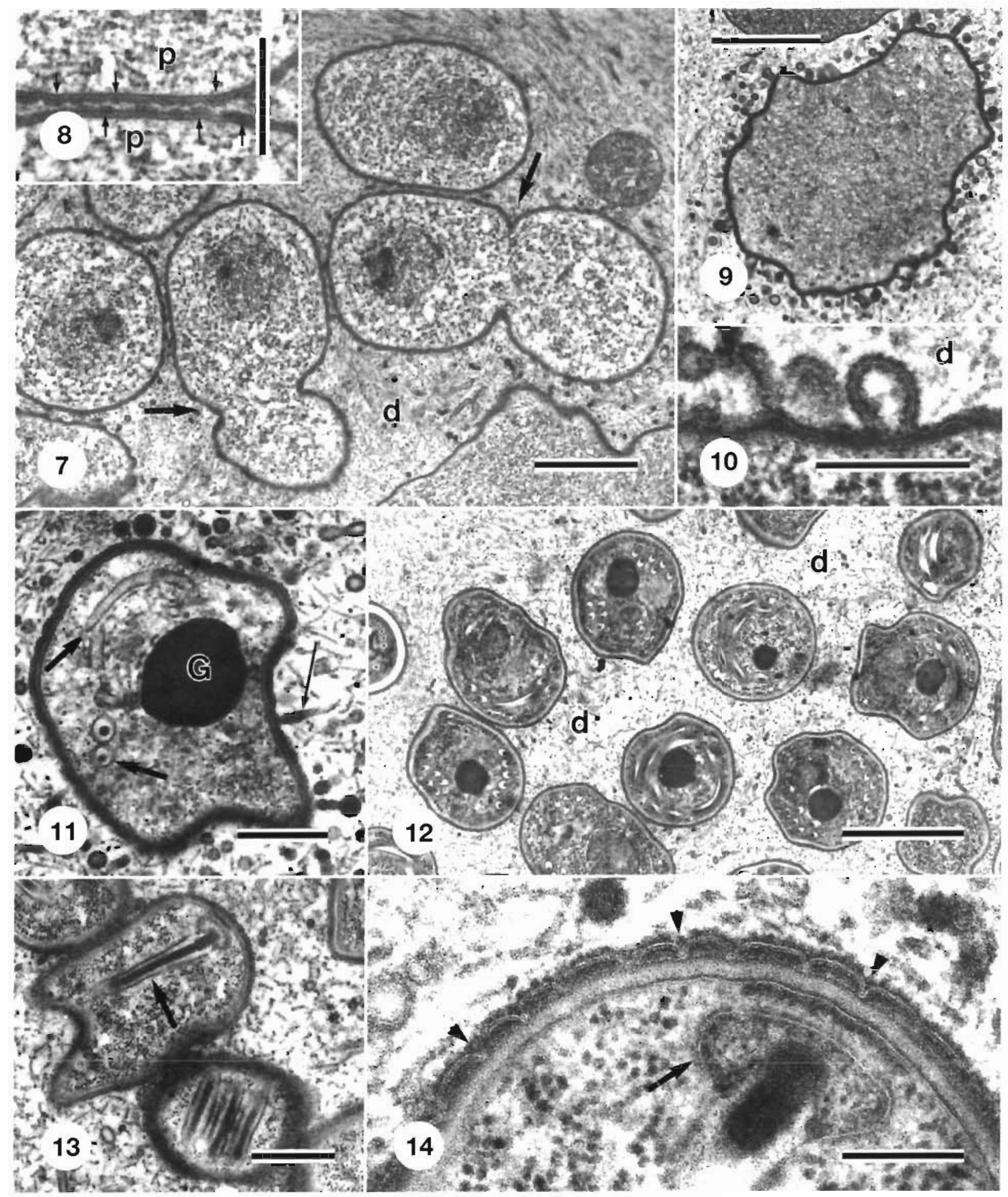

Figs. 7 to 14 Fig 7 Last sporogony division (arrows), sporoblast mother cells giving nse to sporoblasts. $d=$ destroyed sarcoplasm. Scale bar $=1 \mu \mathrm{m}$. Fig. 8. Two adjoining cells from Fig 7 with dense substance deposited in patches (arrows). $p=$ parasite cytoplasm Scale bar $=\overline{05 \mu \mathrm{m}}$ Fig. 9. Part of the sporont (1ts nucleus not in the level of section) with surface extension and surrounding globules Scale bar $=1 \mu \mathrm{m}$. Fig. 10. Blisters delaminatung from the sporont cell wall Scale bar $=0.33 \mu \mathrm{m}$. Fig. 11 . Early sporoblast still surrounded by vesicles and a few tubules (thın arrow) whth a dense globule $(G)$ and first traces of the polar tube (thick arrows) Scale bar $=05 \mu \mathrm{m}$ Fig 12 A group of sporoblasts with dense globules and polar tube in formation. Scale bar $=2 \mu \mathrm{m}$. Fig 13 The straight part of the early polar tube, extending from a germinal polar sac (arrow). Scale bar $=0.5 \mu \mathrm{m}$. Fig. 14. Apex of an immature spore with the incipient polar sac (arrow) and polar tube, with developing endospore and already formed exospore divided into a mosalc of raised fields separated by furrows (arrowheads). Scale bar $=200 \mathrm{~nm}$ 


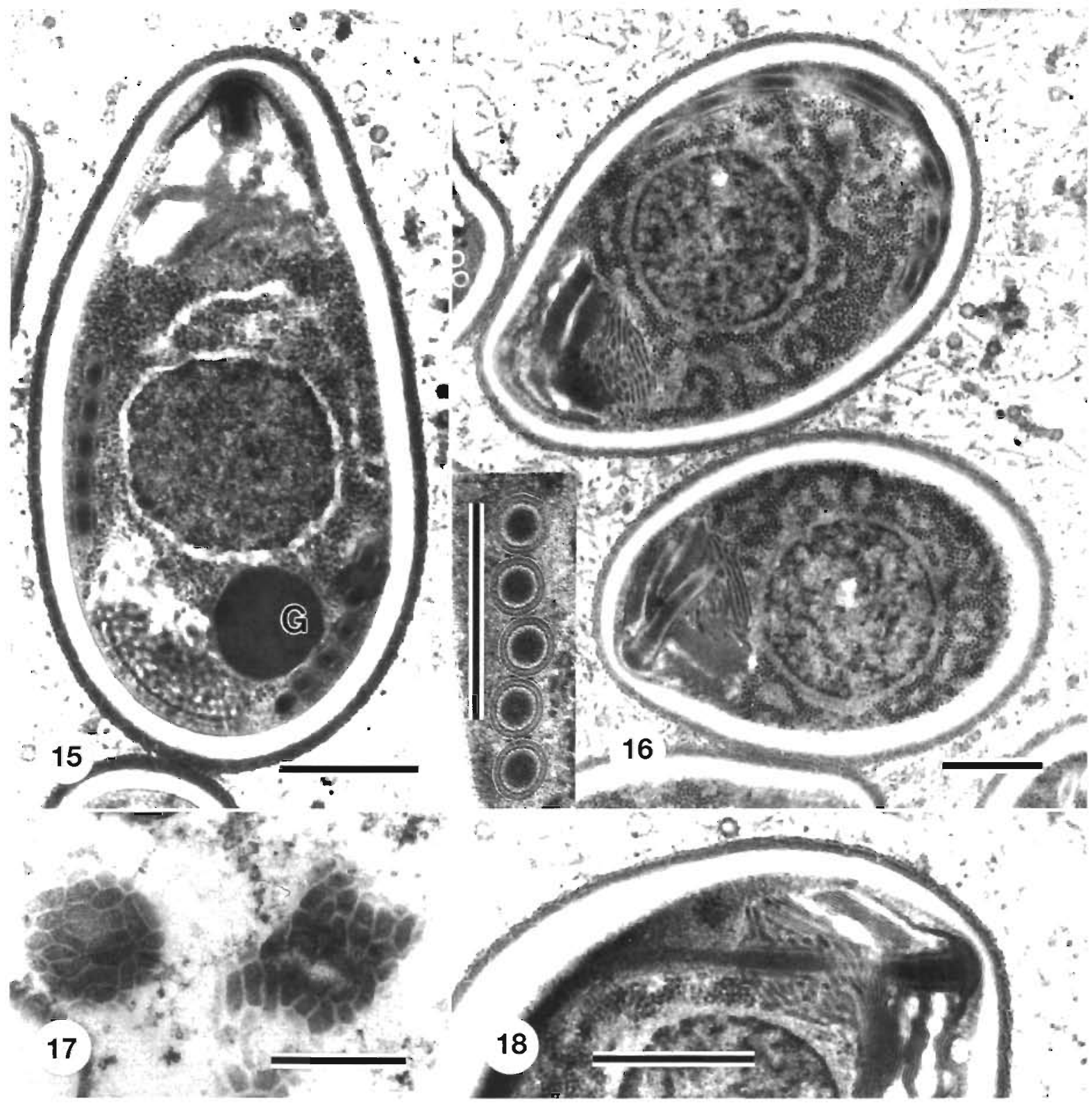

Figs. 15 to 18. Fig. 15. An immature spore still with its dense globule (G) associated with leftovers of the Golgi network to its left Fig. 16. Almost longitudinal sections of 2 mature spores; note the 2 parts of the polaroplast and chains of polyribosomes. Inset: transverse section of the 5 coils of the polar tube. Fig. 17. Grazing section of the exospore fields. Fig. 18. Spore apex with the 2 parts of the polaroplast. Scale bars $=0.5 \mu \mathrm{m}$

The anchoring disc of the polar tube was subterminal, being shifted laterally from the anterior apex (Fig. 16). The straight part of the tube extended obliquely posteriad. The range of the number of turns of the polar tube coil was 4 to 7 , usually 5 or 6 , the mode being $5(n=45)$. The polar tube revealed alternating lucent and dense layers around a dense core on transverse section 4 (Fig. 16, inset).

The membraneous wall of the polar sac covered the polaroplast, which reached to about one third of the spore length. In the anterior lamellar part of the polaroplast there was a stack of approximately 12 la mellae, each approximately $12 \mathrm{~nm}$ across. The posterior part of the polaroplast consisted of up to 9 very flat vesicles, approximately $24 \mathrm{~nm}$ thick, with dense contents (Figs. $16 \& 18$ ).

The single spherical nucleus contained a chromatin network and lacked a nucleolus. The sporoplasm cytoplasm contained masses of polyribosomes appearing on sections as bands or rings. The posterior part of the 
spore contained an irregularly torn space, indicating the position of the posterior vacuole.

Anomalous spores were also found, revealing e.g. 2 nuclei and 2 sets of polar tube, or there was a polar tube with more than one dense core, or there was no tube at all.

Parasite stages proliferated in disintegrated sarcoplasm extending rather far from the parasite stages; no traces of its normal appearance were preserved. Predominant structures in the matrix, in which the microsporidia were embedded, were tubule-like fibrils with a diameter of 10 to $12 \mathrm{~nm}$ (Fig. 4) and vesicles with a diameter of $100 \mathrm{~nm}$, rarely up to $300 \mathrm{~nm}$, with dense walls (Fig. 15). Sometimes osmiophil globules up to $500 \mathrm{~nm}$ in size occurred, and, exceptionally, a persisting host cell nucleus. In addition, there were microfibrils and fine particles.

\section{DISCUSSION}

\section{Taxonomic assignment and diagnosis of the new genus}

The microsporidian described above is obviously identical to Microsporidium arthuri Lom, Dyková and Shaharom, 1990 recorded from the same host; the spores are identical in shape and only insignificantly different in size (average values $3.1 \times 2.1 \mu \mathrm{m}$ in the latter vs $3.1 \times 1.9 \mu \mathrm{m}$ in the former) and also possess an exospore raised in an irregular mosaic of fields (Lom et al, 1990). Unlike in the earlier finding of $M$. arthuri, the developmental stages could be observed and thus a generic assignment is possible. There was no xenoma formation, diplokarya or sporophorous vesicles (and also no precocious formation of extrusion apparatus already in sporonts). Thus the parasite cannot be identified as belonging to any of the known fish infecting genera listed in the introduction. Because it is generally accepted that it is hardly possible for a microsporidian genus to occur in both invertebrates and vertebrates, we cannot assign it to any of the invertebrate infecting genera. In addition, it would be difficult to find any with corresponding features. The present species also has features making it impossible to assign to any of the genera infecting man and mammals, i.e. Brachiola Cali, Takvorian, Lewin, Rendel, Sian, Wittner, Tanowitz, Keohane and Weiss, 1998, Encephalitozoon Levaditi, Nicolau and Schoen, 1923. Enterocytozoon Desportes, Le Charpentier, Galian, Bernard, Cochan-Priollet, Lavergne, Ravisse and Modigliani, 1985, Vittaforma Silveira and Canning, 1995 and Trachipleistophora Hollister, Canning, Weidner, Field, Kench and Marriot, 1996.

Thus we propose to establish for the species from Pangasius sutchi a new genus, Kabataia gen. n., named in honour of the eminent Canadian fish parasitologist of Polish origin, Dr Zbygniew Kabata. The diagnosis of Kabataia is as follows:

(1) Nuclei are isolated at all stages of development.

(2) Developmental stages are always in direct contact with host cell cytoplasm which has been degraded and has lost its normal structure; xenoma formation is absent.

(3) Merogony stages are multinucleate, dividing by plasmotomy and binary fission.

(4) Sporogony sequence starts by transformation of a multinucleate meront into a sporogonial plasmodium. It gradually develops a marked cell wall. No sporophorous vesicles are formed. The plasmodium segments later into uninucleate sporoblast mother cells, dividing eventually to produce 2 sporoblasts.

(5) Mature spores have an isofilar polar tube and polaroplast consisting of 2 distinctly different parts. The surface of the exospore is divided into small fields.

Microsporidium arthuri is reassigned to this genus as Kabataia arthuri (Lom, Dyková and Shaharom, 1990) comb. nov. Features possibly proper to this species only may be tubular extensions associated with the surface of sporogony stages, sporoblasts with characteristic single dense globules and sporoplasm containing copious polyribosomes.

Microsporidium seriolae Egusa, 1982, causing extensive lesions in the trunk muscle of juveniles of cultured marine yellowtails Seriola quinqueradiata in Japan, reveals similar features (Egusa 1982). There is no xenoma formation and no diplokarya at any stage of development. The spores are of similar shape and size, with 4 to 5 coils of the polar tube. Merogony stages are not known. The presence of muitinucleate sporogonial plasmodia was described, which segment to give rise (directly?) to sporoblasts. The features recorded correspond to those of the genus Kabataia and hence we propose, warranting confirmation by further study, to reassign $M$. seriolae into the genus Kabataia as K. seriolae (Egusa, 1982) comb. nov.

A very similar species, a Microsporidium sp., was described by Egusa et al. (1988) from the muscies of another cultured marine fish in Japan, Pagrus major Because of slightly different size of spores, which had 7 coils of polar tube and a different host, they were hesitant to identify it with $M$. seriolae. The description of the species, however incomplete it may be, leaves no doubt that it is a Kabataia sp. too.

Microsporidium takedai (Awakura, 1974) recorded from lesions in trunk muscles of cultured salmonids of the genera Oncorhynchus, Salmo and Salvelinus in Hokkaido, Japan, has spores of shape and size very similar to the preceding species. Other features agree, too $i$ however, according both to Awakura (1974) and 
Miki \& Awakura (1977) the species forms cylindrical multinucleate meronts which divide into uninucleate cells. These cells transform directly into sporonts producing sporoblasts by binary fission. A revision may be needed to confirm this course of sporogony; for the time being, it seems to be a taxon different from Kabataia.

Finding an appropriate place for Kabataia in the classification of Microsporidia poses difficulties. In the classification of Sprague et al. (1992) it cannot be assigned to the class Dihaplophasea (absence of diplokaryon) and none of the families of the second class Haplophasea can accommodate it either. This classification-like the others-will probably no longer be tenable in view of recent molecular findings and assumptions that the diplokaryon as well as the sporophorous vesicle could have developed several times during microsporidian evolution (see Nilsen et al. 1998). Thus the classificational categories even at the level of families are of temporary value. However, we face problems even in finding genera with features similar to Kabataia. We refrain from establishing a new family since we deem it advisable to have more ultrastructural data on related species and a molecular analysis.

\section{Ultrastructural comparison with other microsporidia}

Some ultrastructural features of Kabataia arthuri invite relevant comparisons with species across a large microsporidian range, showing that they need not be special to $K$. arthuri.

Deposition of a dense material on the cell surface of sporogony stages during plasmotomy of sporogonial plasmodium in thick rounded patches can be compared e.g. to a similar process in Tuzetia debaissieuxi (Jírovec, 1943), see Loubes and Maurand (1976), or in Nosema tractabile Larsson, 1981 (Larsson 1986b).

A relatively small volume of polaroplast can also be found in other microsporidia like Microsporidium sp. 11 of Faye (1992) infecting fishes or Parathelohania illinoisensis infecting invertebrates (Hazard 1975). The posterior part of polaroplast-i.e. lamellae containing dense substance - is reminiscent of the same substance enclosed in lamellae in immature spores of Nosema algerae (Canning \& Sinden 1973); in mature spores, only dense 'bodies' are left below the polaroplast lamellae and were termed 'polaroplast precursors' by Sinden \& Canning (1974). A similar dense substance is enclosed in the posterior part of the polaroplast in lamellae as in Vavraia holocentropi Larsson, 1986 (Larsson 1986b), in flat vesicles in Episeptum inversum (Larsson 1986a) or in tubular structures as in Microsporidium chloroscombri (Faye 1992).
Preliminary observations (Lom \& Dyková 1992) on an unidentified Microsporidium species from a goby supplied by Dr Nagasawa from Japan have revealed a mosaic of elongated fields of exospore layer, similar to that in Kabataia arthuri.

\section{Destruction of muscle cells}

Some microsporidia infecting muscles of their host do not inflict heavy damage on the surrounding muscle cell they are embedded in and their developmental stages border on an almost intact cell structure-e.g. in Thelohania butleri Johnston, Vernick and Sprague, 1978 from shrimp muscle (Johnston et al. 1978), Pleistophora littoralis and P. typicalis from fish muscle (Canning et al. 1979, Canning \& Nicholas 1980) or $P$. myotrophica in the toad Bufo bufo (Canning \& Lom 1986). The same applies to some myxosporeans, e.g. from the genus Kudoa, developing inside the fish muscles (Lom et al. 1983). This is not a general rule, however. $P$. hyphessobryconis stages are surrounded by a halo of completely disintegrated sarcoplasm (Canning \& Lom 1986); this destruction, however, does not come close to reaching the extent of the damage caused by Kabataia. In the latter genus, an enzymatic action obviously exists, unlike in most other microsporidia but in a way similar to that postulated in muscle liquefying myxosporeans in marine fishes (Langdon 1991).

Acknowledgements. This work was supported by grants of the Grant Agency of the Czech Republic No. 524/98/0589 and of the Grant Agency of the Academy of Sciences of the Czech Republic No. K2-022-601. Skilful technical assistance of Mrs M. Nešpůrková and J. Bíca is gratefully acknowledged.

\section{LITERATURE CITED}

Amigo JM, Salvado H, Gracia MP, Vivarès CP (1996) Ultrastructure and development of Microsporidium ovoideum (Thélohan, 1895) Sprague, 1977, a microsporidian parasite of the Red Band Fish (Cepola macrophthalma L.) - redescription of the organism and reassignment to the genus Microgemma Ralphs and Matthews. Eur J Protistol 32: $532-538$

Awakura T (1974) Studies on the microsporidian infection in salmonid fishes. Sci Rep Hokkaido Fish Hatchery No. 29: $1-93$

Canning EU, Lom $\mathrm{J}$ (with cooperation of Dyková I) (1986) Microsporidia of vertebrates. Academic Press, London

Canning EU, Nicholas JP (1980) Genus Pleistophora (Phylum Microspora): redescription of the type species, Pleistophora typicalis Gurley, 1893 and ultrastructural characterization of the genus. J Fish Dis 3:317-338

Canning EU, Sinden RE (1973) Ultrastructual observations on the development of Nosema algerae Vávra and Undeen (Microsporida, Nosematidae) in the mosquito Anopheles stephensi Liston. Protistologica 9:405-415

Canning EU, Hazard EI, Nicholas JP (1979) Light and elec- 
tron-microscopy of Pleistophora sp. from skeletal muscle of Blennius pholis. Prostistologica 15:317-332

Docker MF, Kent ML, Hervio DML, Weiss L, Cali A, Devlin RH (1997) Ribosomal DNA sequence of Nucleospora salmonis Hedrick, Groff and Baxa, 1991 (Microsporea, Enterocytozoonidae): implications for phylogeny and nomenclature. J Eukaryot Microbiol 44:55-60

Egusa S (1982) A microsporidian species from yellowtail juveniles, Seriola quinqueradiata, with 'Beko' disease. Fish Pathol 16:187-192

Egusa S, Hatai K, Fujimako Y (1988) Notes on microsporidium species, the etiological agent of 'Beko' disease in Red Sea Bream juveniles, Pagrus major. Fish Pathol 23:263-267

Faye N (1992) Microsporidies des poissons des côtes sénégalaises: faunistique, biologie, ultrastructure. Thesis, Université Montpellier II, Sciences et Techniques du Languedoc

Hazard EI (1975) Revision of Microsporida (Protozoa) close to Thelohania, with descriptions of one new family, eight new genera, and thirteen new species. Technical Bull No. 1530, Agricultural Research Service, US Dept Agriculture, Washington, DC

Johnston LB, Vernick SH, Sprague V (1978) Light and electron microscope study of a new species of Thelohania (Microsporida) in the shrimp Pandallus jordani. J Invertebr Pathol 32:278-290

Langdon JS (1991) Myoliquefaction post-mortem ('milky flesh') due to Kudoa thyrsites (Gilchrist) (Myxosporea: Multivalvulidea) in mahi mahi, Coryphaena hippurus L. J Fish Dis 14:45-54

Larsson R (1986a) Ultracytology of a tetrasporoblastic microsporidium of the caddisfly Holocentropus picicornis (Trichoptera, Polycentropodida), with description of Episeptum inversum gen. et sp. nov. (Microspora, Gurleyidae). Arch Protistenkd 131:257-279

Editorial responsibility: Wolfgang Körting, Hannover, Germany
Larsson $R$ (1986b) Ultrastructure, function and classification of Microsporidia. In: Corliss JO, Patterson DJ (eds) Progress in protistology, Vol 1. Biopress Ltd, Bristol, p 325-390

Lom J, Dyková I (1992) Protozoan parasites of fish. Developments in aquaculture and fisheries science, 26. Elsevier, Amsterdam

Lom J, Dyková I, Lhotáková Š (1983) Kudoa lunata n. sp. (Myxozoa, Myxosporea) and notes on the nature of muscular 'cysts' of the genus Kudoa. Arch Protistenkd 127: $387-397$

Lom J, Dyková I, Shaharom F (1990) Microsporidium arthuri n. sp., parasite of Pangasius sutchi (Pangasiidae, Siluroidea) in South-East Asia. Dis Aquat Org 8:65-67

Loubes C, Maurand J (1976) Etude ultrastructurale de Pleistophora debaissieuxi Jírovec, 1943 (Microsporida): son transfert dans le genre Tuzetia Maurand, Fize, Michel et Fenwick, 1971 et remarques sur la structure et la genèse du filament polaire. Protistologica 12:577-591

Miki S, Awakura T (1977) The fine structure of Glugea takedai Awakura, 1974 (Microsporida, Nosematidae). Sci Rep Hokkaido Fish Hatchery No. 32:1-19

Nilsen F, Endresen C, Hordvik I (1998) Molecular phylogeny of microsporidians with particular reference to species that infect the muscles of fish. J Eukaryot Microbiol 45: $166-170$

Shaw RW, Kent ML (1999) Fish Microsporidia. In: Wittner M, Weiss LM (eds) The Microsporidia and microsporidiosis. Am Soc Microbiol, Washington, DC, p 418-446

Sinden RE, Canning EU (1974) The ultrastructure of the spore of Nosema algerae (Protozoa, Microsporida), in relation to the hatching mechanism of microsporidian spores. J Gen Microbiol 85:350-357

Sprague V, Becnel JJ, Hazard EI (1992) Taxonomy of phylum Microspora. Crit Rev Microbiol 18:285-395

Submitted: March 7, 1999; Accepted: June 30, 1999 Proofs received from author(s): September 20, 1999 